\title{
The Art of Art History: A Professional Allegory Irving Lavin
}

Leonardo, Vol. 29, No. 1. (1996), pp. 29-34.

S $\quad$ t

http://links.jstor.org/sici?sici=0024-094X\%281996\%2929\%3A1\%3C29\%3ATAOAHA\%3E2.0.CO\%3B2-5

Leonardo is currently published by The MIT Press.

Your use of the JSTOR archive indicates your acceptance of JSTOR's Terms and Conditions of Use, available at http://www.jstor.org/about/terms.html. JSTOR's Terms and Conditions of Use provides, in part, that unless you have obtained prior permission, you may not download an entire issue ofajournal or multiple copies of articles, and you may use content in the JSTOR archive only for your personal, non-commercial use.

Please contact the publisher regarding any further use of this work. Publisher contact information may be obtained at http://www.jstor.org/journals/mitpress.html.

Each copy of any part of a JSTOR transmission must contain the same copyright notice that appears on the screen or printed page of such transmission.

The JSTOR Archive is a trusted digital repository providing for long-term preservation and access to leading academic journals and scholarly literature from around the world. The Archive is supported by libraries, scholarly societies, publishers, and foundations. It is an initiative of JSTOR, a not-for-profit organization with a mission to help the scholarly community take advantage of advances in technology. For more information regarding JSTOR, please contact support@jstor.org. 


\title{
The Art of Art History: A Professional Allegory
}

\author{
Irving Lavin
}

ABSTRACT

Bertrand Russell, the great English philosopher, once defined truth as what happens when someone confronted with the equation $2+2=4$ exclaims, "Aha!" What Russell meant was that we recognize truth when we see it, but in the last analysis we cannot define precisely what it is. The basis of my art-historical life is a somewhat analogous principle, which I would describe as the "light-bulb effect." When a meaningful observation is made about a work of art, at least an observation meaningful to me, an inner light goes on. I cannot say what makes the observation meaningful or why the bulb lights up, but I can illustrate what I mean. One of the standard cliches about the elaborate initial pages in early Celtic manuscripts such as the Book of Kells is that they reflect a barbaric love of decoration (Fig. 1). By contrast, I once heard Meyer Schapiro say that for the Celts, who were emerging from a primitive state of illiteracy, the letters of the alphabet had something of the quality of magical signs. With the first statement, the inner light stayed dark; with the second, it shone brightly: Schapiro's observation allowed one to see that the Celtic illuminator had succeeded in conveying both the mystery and the meaning of the Gospel by fusing the wild gyrations of his native interlace tradition with the order and discipline inherent in written language. Aha!

Since then my life has never been quite the same. I realized, for example, that more than a millennium later Thomas Mann recaptured something of this experience in his short story about the Tablets of the Law, called Das Gesetz, in which it turns out that what Moses was really doing on Mount Sinai all those 40 days and nights was inventing the art of writing (Bedeutungszauber- - "meaning-magic," Mann calls it); he describes the agonizing process by which Moses reasoned his way from thought to words to sounds to signs, and he points out the awesome, one might say miraculous, consonance between the universal verbal code embodied in the alphabet, which can be used to write any language, and the universal moral code embodied in the Decalogue. The medium was thus inseparable from the message, and equally inspired. I realized, for another example, that almost the opposite process had taken place a millennium before the Celtic manuscript in a group of mosaic pavements of the fourth century ti.c. found in a grand and sumptuous house at Olynthos in Greece (Fig. 2). Here the

Irving Lavin, Institute for Advanced Study, Olden Lane, Princeton, NJ 08540, U.S.A.

This paper was first published in Art News 82 (1983) pp. 96-101. It was later presented at the International Workshop on Art and Science, which was organized by the World Academy of Art and Science and presented by Ente Nazionale di Energie Alternative (ENEA) in cooperation with the United Nations Educational, Scientific and Cultural Organization (UNESCO) and the European Economic Community (ECC), in Vinci, Italy, 11-13 December 1992. The proceedings of the conference, including this article, were published in Art and Science: Studies from the World Academy of Art and Scie
issue of World Futures: The journal of General Evolution 40 Nos. 1-3 (1994).

figural compositions with decorative borders display all the beauty, order and discipline we normally associate with Greek thought (Fig. 3); traces of this rationality are discernible in certain of the floors where augural inscriptions, such as "Good Fortune" or "Lady Luck," are accompanied by various apotropaic symbols-circles, spirals, swastikas, zigzags, etc. (Fig. 4); finally, the entire composition may be dissolved in an amorphous chaos from which the magical signs shine forth mysteriously helter-skelter, like stars in the firmament-the random arrangement is as deliberate

Fig. 1. Chi-Rho page from the Book of Kells, Dublin, Trinity College Library, fol. 34r [51.

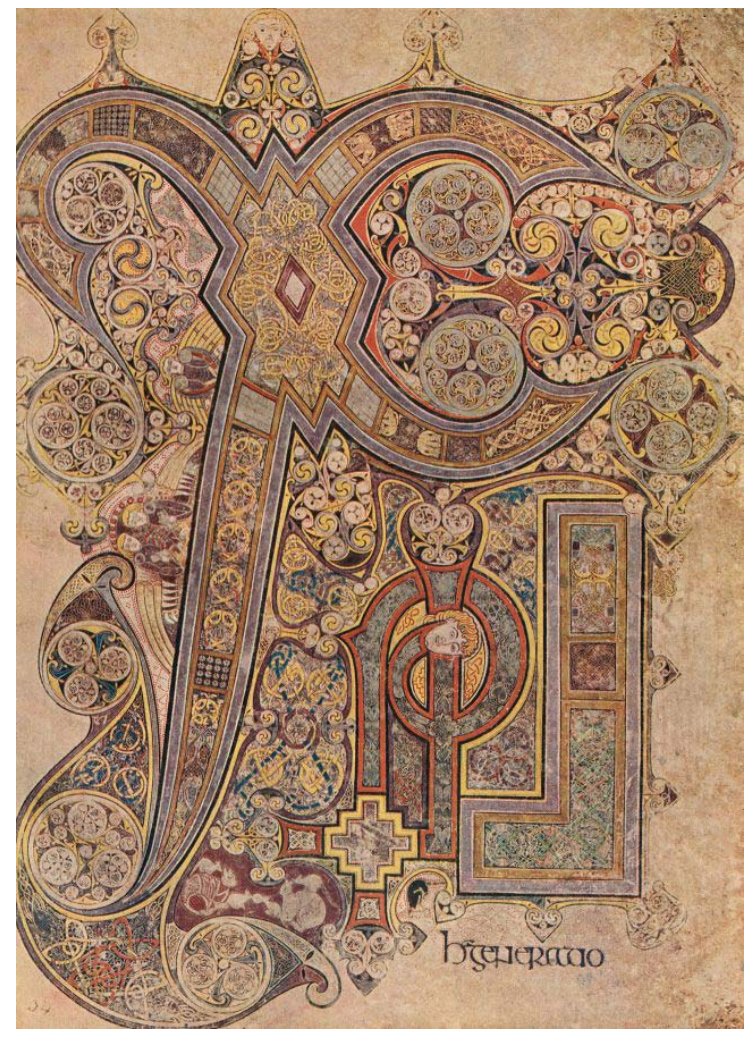




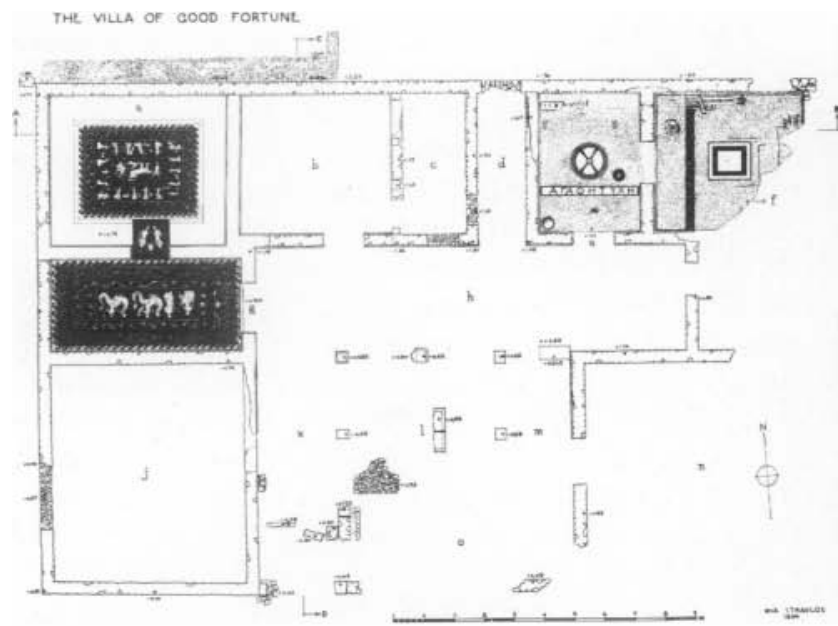

Fig. 2. Plan view, Villa of Good Fortune, Olynthos [6]. (Courtesy of the Archaeological Institute of America)

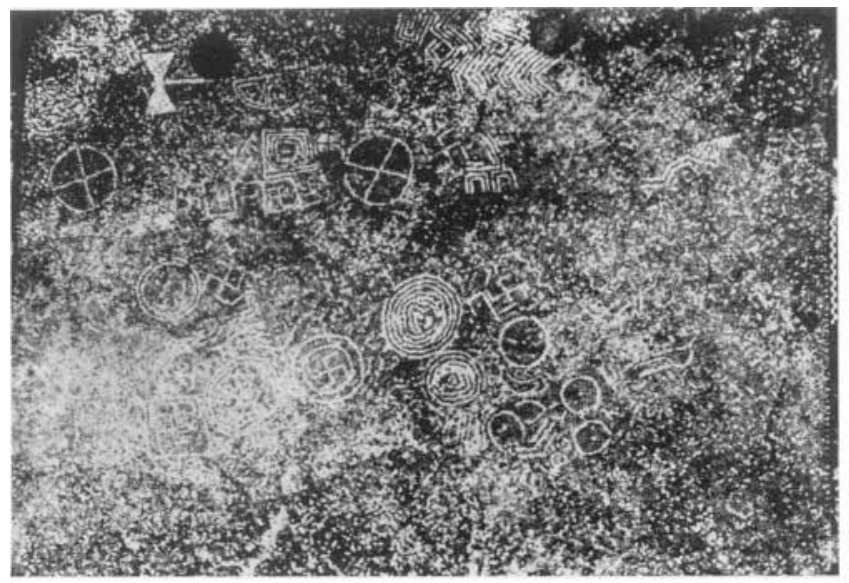

Fig. 4. Pebble mosaic with inscriptions and symbols (Double Axe, Swastika, Wheel of Fortune), Olynthos, Villa of Good Fortune [8]. (Courtesy of the Archaeological Institute of America)

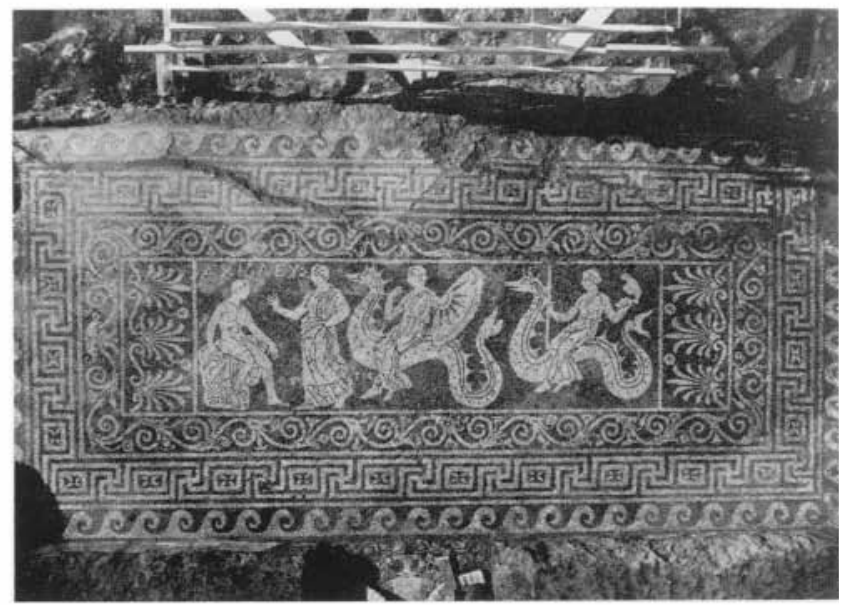

Fig. 3. Pebble mosaic with a representation of Achilles, Thetis and Nereids, at Olynthos, Villa of Good Fortune [7]. (Courtesy of the Archaeological Institute of America)

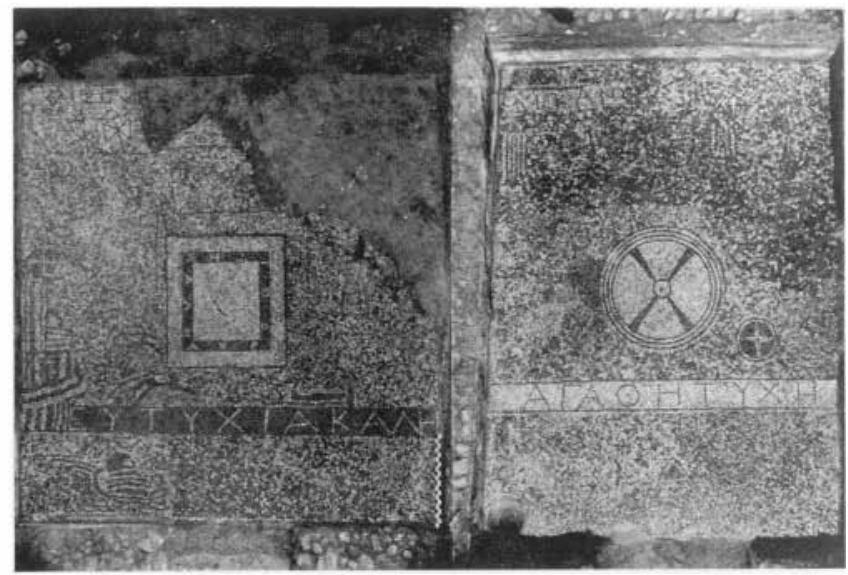

Fig. 5. Pebble mosaic with many symbols, including swastika and double axe, at Olynthos, House A xi 9 [9]. (Courtesy of the Archaeological Institute of America) and significant as the signs themselves (Fig. 5).

It became clear, in sum, that the Celtic initial page was a fundamental statement by the artist concerning the nature of communication, and that Schapiro's observation was an equally fundamental decipherment of the statement by someone whose light bulb had lit up before mine. The observation laid bare an area of common experience that joins human beings across the centuries, and, within its own context, it will stand like Einstein's E =

I do not intend this reference to science simply as a metaphor. Einstein used mathematical symbols for dealing with physical nature; Schapiro uses words for dealing with human nature. Both define specific relationships between previously disconnected, indeed seemingly incompatible conceptual realms-energy versus mass on the one hand, divine inspiration versus rational discourse on the other. Schapiro's statement has the precision and validity of a natural law, and to limit its context to art history is too circumspect. It is quite different from an ordinary fact of chronology, iconography or style, for two interrelated reasons. One is that it links the work of art, both as a functional artifact (that is, a Gospel book) and as a visual expression (that is, the Insular style), to an aspect of human experience in general (that is, our apprehensions of the supernatural). The second effect of Schapiro's theorem is that by relating the work's particular form and meaning to a universal context, it elicits a compelling sense of "understanding" what is observed, and thus meets the chief requirement of a science in the fullest sense of the term.

A curious point, perhaps significant of our positivist Anglo-Saxon heritage, is that we have in English no way to de-scribe this intersection between human nature and natural law. The field of psychobiology may be said to operate at the same intersection, but on a different level, and we have no real equivalent for the French science bumaine or the German Geisteswissenschaft. About the best we can do in terms of traditional categories is the old British academic notion of "moral science."

Even more curious and significant, however, is the fact that the most appropriate designation I can think of for Schapiro's observation comes from a similar effort at self-definition in the field that might seem to be the most inimical of all, namely mathematics. A colleague of mine at the Institute for Advanced Study in Princeton, the Swiss mathematician Armand Borel, has recently published a paper titled "Mathematics: Art and Science" [ 1 ]. The title is carefully formulated to indicate Borel's syncretic 


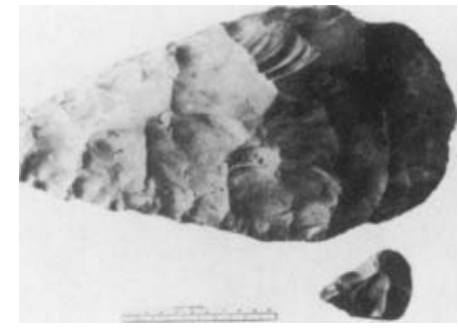

Fig. 6. Acheulian hand-axe from Furze Platt near Maidenhead (Department of Geology [Natural History], British Museum, London) [10]. (Copyright (C) 1968 The University of Chicago Press)

position in what has evidently been a long-standing debate in his field. He argues that mathematics is an art because aesthetic criteria play an important role in judging mathematical concepts, and because the mathematician proceeds in the same disorderly, intuitive and sometimes inspired way as does the artist. Mathematics is also a science because it strives for generally valid theoretical principles, which it often reaches by "experimenting" with individual cases. What chiefly differentiates mathematics from the arts as well as the sciences is that mathematics deals exclusively with ideas-ideas which are shared by others and so are felt to have an objective existence comparable to that of the physical world. This inference leads Borel to the luminous definition of mathematics as a "natural science of the intellect."

I want to adapt Borel's phrase and define art history as a natural science of the spirit. I like this notion because it suggests the dual nature of our discipline, which seeks not only to describe the form, meaning and development of material culture but also to relate them to the thoughts, feelings and conditions that produce them. The formulation is appealing also because it acknowledges that the inspired practitioners of our discipline, such as Schapiro, can produce insights whose truth, precision and beauty a mathematician might well appreciate.

Like any science, my natural science of the spirit is based on certain assumptions, that is, concepts that I call assumptions because I doubt whether in the long run any of them is demonstrably valid or invalid. There are five assumptions, of which the first is that anything man-made is a work of art, even the lowliest and most purely functional object. Man, indeed, might be defined as the art-making animal, and the fact that we choose to regard only some man-made things as works of art is a matter of conditioning. Our conventions in this respect are themselves, in a manner of speaking, works of art. I take at least some comfort in my perversity from the anthropologists, as witness a passage concerning an unusually large and splendid prehistoric hand ax (Fig. 6), in Kenneth P. Oakley's Man the Tool-maker.

The artistic impulse appears to have manifested itself in exceptional individuals long before the Upper Paleolithic period, indeed probably from the dawn of tool-making. The great Acheulian hand-axe from the gravels at Furze Platt, Maidenhead [in England], is evidently the product of an artistic craftsman. It has been suggested that a masterpiece of such size and beauty may well have been treasured by the tribe [2].

Even here, however, one wonders what the creator of the Maidenhead ax would have had to achieve to earn the title of sculptor rather than "artistic craftsman," and whether his creation would really have been recognized as a masterpiece had he chipped the flint to average or less than average size.

The second assumption is that everything in a work of art was intended by its creator to be there. A work of art represents a series of choices and is therefore a totally deliberate thing-no matter how unpremeditated it may seem, and even when "accidents" are built into it deliberately. We can never be sure that the artist did not know what he was doing or that he wanted to do something other than what he did-even when he declares himself dissatisfied with his creation. A glaring instance of the sort of art-historical dyslexia this assumption is designed to prevent occurs, oddly enough, in the comments made some years ago in an article by Ernst Gombrich on the visual image and communication [3]. The comments concern two of Van Gogh's best-known compositions, the View of the Artist's Room at Arles and the closely contemporary Night Café (Figs 7, 8). In his letters to his brother Theo and to Gauguin, Van Gogh describes at some length how the view of his bedroom was intended to suggest absolute rest, sleep in general or the repose of the imagination, as he puts it. He emphasizes that he achieved this effect by an extremely simplified, very rich impasto of clear light colors, without modeling and without shadows. He specifically contrasts this work with the Night
Fig. 7. Vincent Van Gogh, The Artist's Bedroom at Arles, oil on canvas, 73.6 x 92.3 cm, 1888-1889. Helen Birch Bartlett Memorial Col lection, 1926.417, Art Institute of Chicago. (Photograph (C) 1994, The Art Institute of Chicago. All Rights Reserved.)

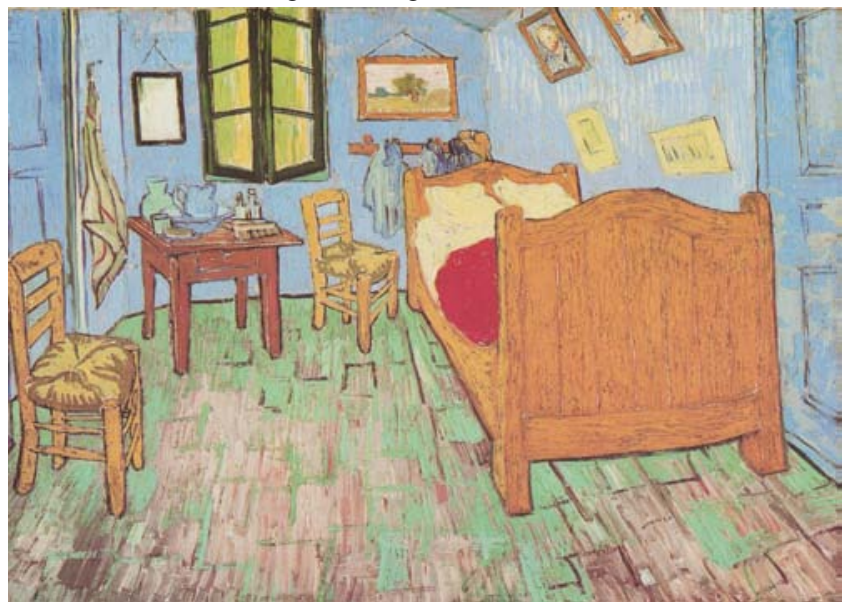

Fig. 8. Vincent Van Gogh, The Night Cafe, oil on canvas, Yale University Art Gallery, New Haven, 1888. (Courtesy of the Yale University Art Gallery, Bequest of Stephen Carlton Clark.)

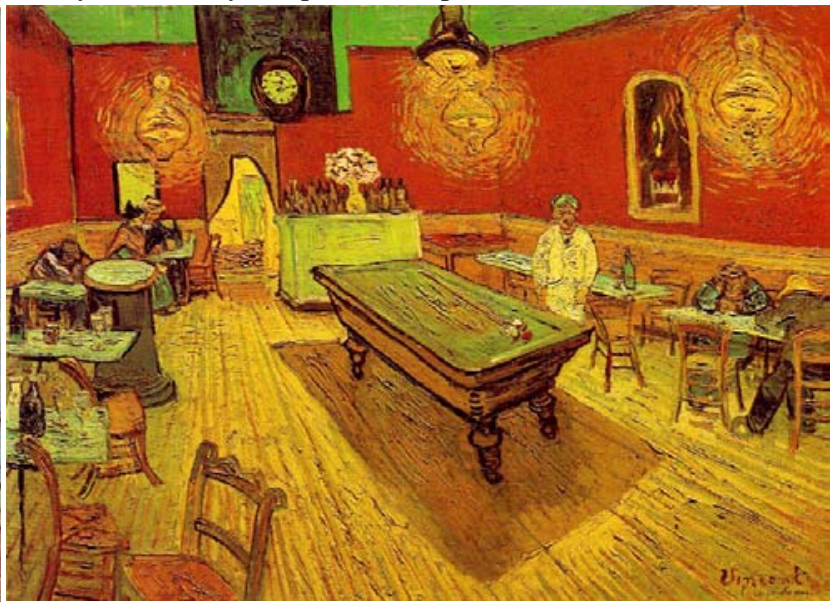




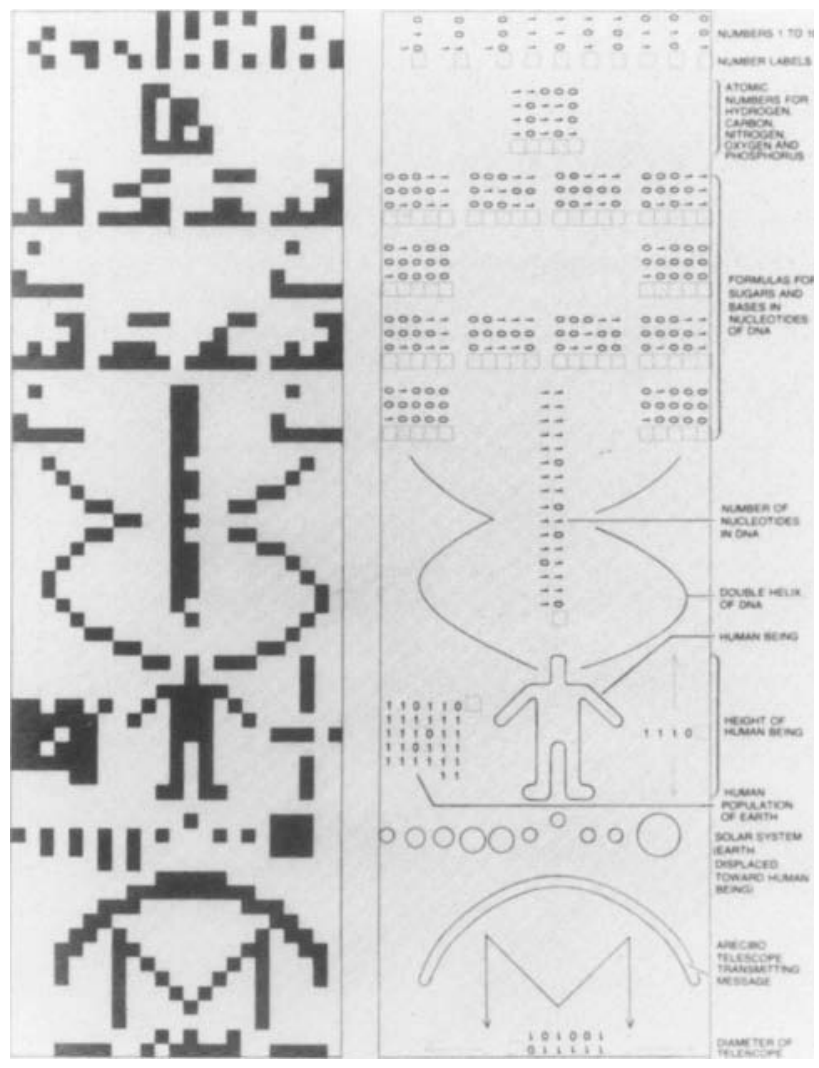

Fig. 9. Interstellar radio message in binary code deciphered in pictures (left) with translation (right). (Illustration by Ilil Arbel. Copyright (C) 1975 Scientific American, Inc. All Rights Reserved.) [11]
Cafe, in which he says he wanted to depict a place where one could go mad or commit a crime. Gombrich wonders whether the bedroom painting does communicate the intended feeling. He had evidently showed a reproduction of the work to a number of "naive subjects," and he reports that none of them hit upon the right meaning, although they knew the picture's title; but he is careful to add that this "failure of getting the message" speaks not against the artist or his work, only against identifying art with communication. Gombrich's test, of

Fig. 10. Pictorial plaque on the Pioneer spacecraft [12].

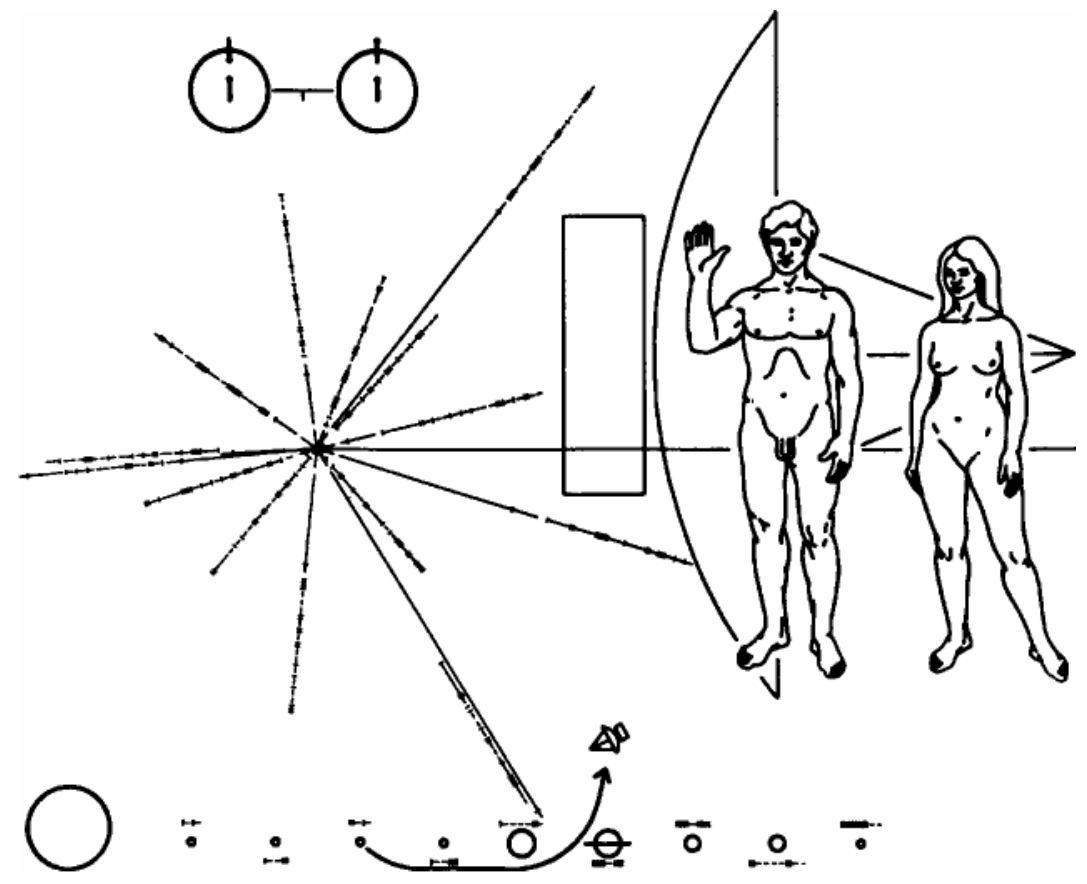

course, was a little like asking the man in the street before Copernicus whether according to his experience the sun moved with respect to the earth or vice versa. Van Gogh evidently had a different, perhaps even a more profound understanding of visio-psychological processes than ordinary people, as different from the ordinary, in fact, as was his notion of painting itself. It may require a leap of the imagination to grasp how the corner of a familiar bedroom painted in thick, bright, flat, shadowless colors could put the imagination to rest-unlike the nightmarish effulgences and mysterious depths evoked by the café scene. But surely there is no failure to communicate here, only a failure to comprehend.

The third assumption is that every work of art is a self-contained whole. It includes within itself everything necessary for its own decipherment. Information gathered from outside the work may be useful, but it is not essential to the decipherment. On the other hand, outside information (which includes information from or about the artist himself) is essential if we want to explain how the work came to have its particular form and meaning. In a sense, the work of art is rather like the encoded messages some optimistic scientists have sent into outer space to be decoded by those famous extraterrestrial intelligent beings who understand the physical universe but nothing of our culture. Two such messages have been transmitted, one via radio telescope (Fig. 9) and the other engraved on plaques attached to space probes (Fig. 10). Both depend on recognition by the little green monsters out there of two kinds of patterns: those reflecting concepts presumably constant throughout the universe, such as numbers and the atomic numbers of the elements, and those which have no such resonance and are therefore peculiar to the transmitting agent and his method of communication. Apart from these common principles, however, the two messages are quite different in form as well as content, and one would have to know a great deal indeed about man and conditions on earth to understand how these particular messages came into being. The work of art has essentially the same structure, except that its message includes emotions and its media involve sense organs which the little green monsters may not possess.

The fourth assumption is that every work of art is an absolute statement. It conveys as much as possible with as little 
as possible. The work of art is 100 per cent efficient, and, to paraphrase Leon Battista Alberti's classic definition of Beauty, nothing could be added, taken away or altered without changing its message. Alberti was referring simply to the relationship among the parts, whereas I mean to include the very substance of the work itself. Again, the critical necrology of our discipline is littered with failures to heed this principle. At one extreme are those who dismissed the more fulsome forms of Baroque art as attempting to say too little with too much. Rubens has fully recovered, I suppose, but Bernini still suffers under this kind of dyslexia, especially when his architecture is compared with Borromini's. At the opposite extreme are those who vilified the Impressionists for saying too much with too little. Degas in particular, that arch-voyeur of the fugitive and the inadvertent, defined explicitly the underlying paradox of his art: "There is no art less spontaneous than mine," he said. "What I do is the result of reflection and study of the great masters; of inspiration, of spontaneity, of temperament, I know nothing.. .. Nothing in art must seem an accident, not even movement." Considering the challenge to conventional values posed by his unorthodox and often indecorous style and subject matter, Degas' paradox is potentially a cruel one, at least for those who fail to comprehend; but of this, too, he gave fair warning with his roguish confession: "A painting is a thing that requires as much cunning, malice and vice as the perpetration of a crime; fake it, and add an accent of nature" [4]. My point is that to avoid being duped-and to be duped is to miss an urgent if often unsettling message-we must treat every work of art as if it were a perfect crime.

The fifth assumption is that every work of art is a unique statement. It says something that had never been said before and will never be said again, by the artist himself or anyone else. Copies or imitations, insofar as they are recognizable as such, are no exception, since no man can quite suppress his individuality, no matter how hard he may try. Conversely, no matter how original the artist is, his work to some extent reflects others, and it is purely a matter of convention that we tend to evaluate works of art by the quantity of difference from their models. We should draw a moral in this connection from the rich fruits borne by the current interest in Roman copies of Greek originals as a field of Roman art (Fig. 11). Much is to be learned not only from when and what the

Romans copied but also from where and how they displayed the copies; most important, perhaps, we are beginning to realize that the very qualities the term "Roman copy" used to convey, in derisive contrast to the originals, constitute an important aspect of the history of style. Multiple photographs such as those shown here are familiar from the older
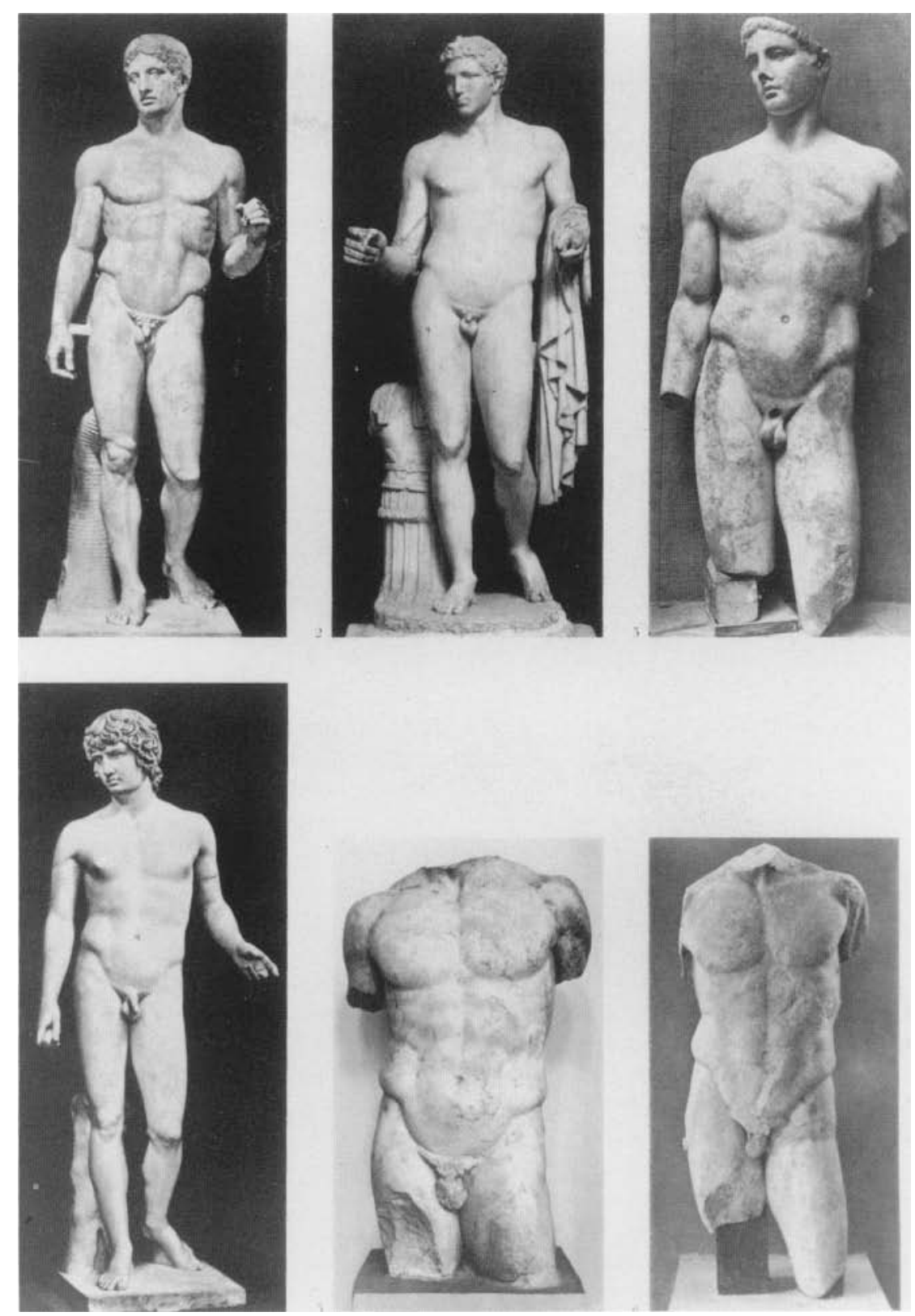

Fig. 11. (above) Roman copies of Doryphoros (three versions in Naples); (below) Hadrianic Antinoos Farnese (Naples, Tunis, Olympia) [13].

literature on ancient art that sought to reconstruct Greek originals by stripping away the ineptitudes of more or less slavish Roman copyists; in this case, the illustrations are from a recent book in which they serve exactly the opposite purpose of revealing how the Romans absorbed and transformed their heritage from Greece. The bittersweet nostalgia for an ideal past

evoked by Hadrianic neoclassicism emanates primarily from the actual reproductions of Polyclitan prototypes. Or consider the early sixteenth-century engraver Marcantonio Raimondi. He made a specialty of reproducing Raphael, and his prints-not one of which is an original composition-were viewed entirely in terms of what they showed or failed to show about the prototypes (Figs 12, 13). We are now becoming aware that in fact Marcantonio expressed a distinct vision of his own to which our understanding of Raphael, of the High Renaissance and of normative art in general, is deeply indebted.

The chief virtue of these assumptions is that they help to assure each human 


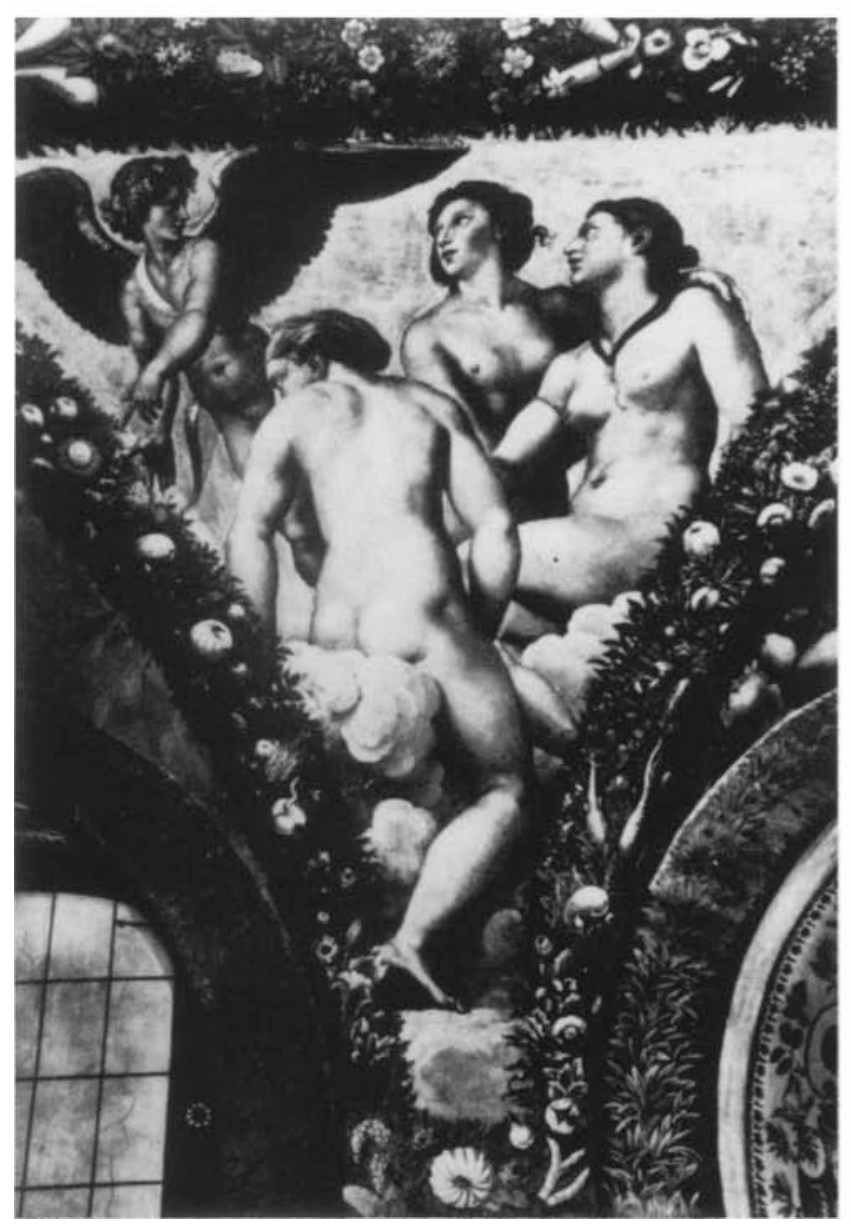

Fig. 12. Raphael, Cupid and the Graces, Rome, Farnesina: spandrel in the Gallery of Psyche.

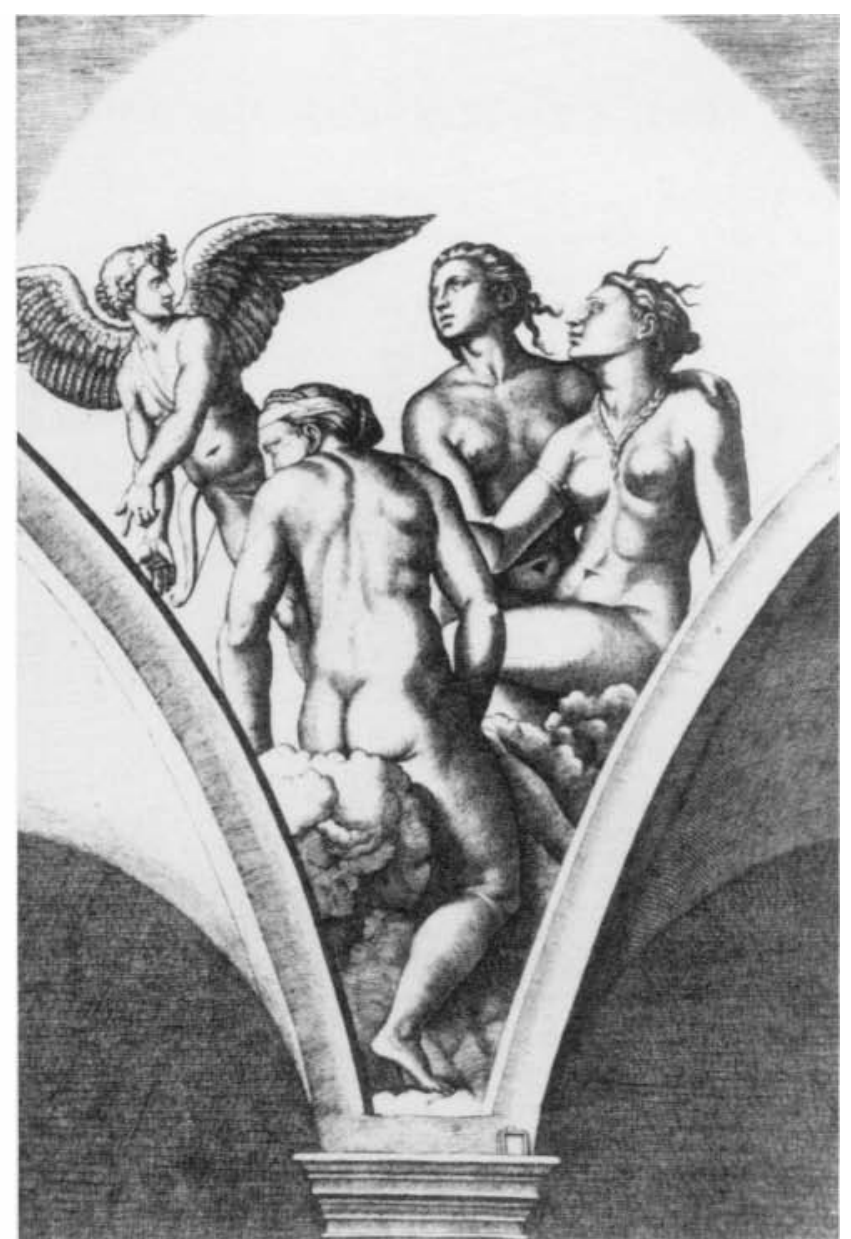

Fig. 13. Marcantonio Raimondi, Cupid and the Three Graces, engraving after Raphael [14]. creation its due. What it is due may be defined as the discovery of the reciprocity it embodies between expressive form and content. To me the brightest light bulbs are those which illuminate the fact that the artist is saying something, and that what he says and the way he says it are one and the same thing. Art most emphatically is a form of communication, and herein precisely lies the art of art history. Ars est celare artem, art is to conceal art, and ours is the paradoxical task-requiring much cunning and some malice-of treating an art as if it were a science.

I do not pretend that my own work has ever met the criteria implicit in any of my assumptions. Yet they are much more to me than philosophical abstractions. They represent the obscure but persistent demons that prod me to think abouta work in the first place, and, once the process begins, to reject as fatuous an explanation such as Celtic love of decoration. They are intellectual pangs of conscience that lead me to mistrust distinctions between conscious and unconscious creativity, between mechanical and conceptual function, between the artist's goal and his achievement. Finally, they are what drive me from the work itself into archives, libraries and classrooms in the hope of coaxing my own filament to conduct.

\section{References}

1. Armand Borel, "Mathematics: Art and Science," The Mathematical Intelligencer 5 (1983) PP. 9-17.

2. Kenneth P. Oakley, Man the Tool-maker (Chicago: Univ. of Chicago Press, 1968).

3. Ernst Gombrich, "The Visual Image," Scientific American 227 (1972) pp. 82-96.
4. Francoise Sevin, "Degas a travers ses mots," Gazette des Beaux-Arts 86, Nos. 238, 248 (1975) p. 38.

5. See the Book of Kells, with a study of Francoise Henry (London: Thames \& Hudson, 1974) pl. 29.

6. David M. Robinson, "The Villa of Good Fortune at Olynthos," American Journal of Archaeology 38 (1934) p. 502, Fig. 1.

7. Robinson [6] pl. 30.

8. Robinson [6] p. 504, Fig. 2.

9. Robinson [6] pl. 31.

10. Oakley [2] pl. 1.

11. Carl Sagan and Frank Drake, "The Search for Extraterrestrial Intelligence," Scientific American 232, No. 5 (1975) p. 87. (Copyright (C) 1975 Scientific American, Inc. All rights reserved.)

12. Sagan and Drake [11] p. 89.

13. See Paul Zanker, Klassizistische Statuen (Mainz: Verlag Philipp von Zabern GMBH, 1974) pl. 5.

14. See Innis Shoemaker, The Engravings of Marcantonio Raimondi (Lawrence, KA: Spencer Museum of Art, 1981) Fig. 45. 
http://www.jstor.org

\section{LINKED CITATIONS \\ -Page lof1 -}

You have printed the following article:

\section{The Art of Art History: A Professional Allegory}

Irving Lavin

Leonardo, Vol. 29, No. 1. (1996), pp. 29-34.

$\mathrm{S}$ t a b l e $\mathrm{U}$ R $\mathrm{L}$ :

http://links.jstor.org/sici?sici=0024-094X\%281996\%2929\%3A1\%3C29\%3ATAOAHA\%3E2.0.CO\%3B2-5

This article references the following linked citations. Ifyou are trying to access articles from an off-campus location, you may be required to first logon via your library web site to access JSTOR. Please visit your library's website or contact a librarian to learn about options for remote access to JSTOR.

\section{References}

\section{${ }^{6}$ The Villa of Good Fortune at Olynthos}

David M. Robinson

American Journal ofArchaeology, Vol. 38, No. 4. (Oct. - Dec., 1934), pp. 501-5 10.

$\mathrm{S}$ t a b l e $\mathrm{U}$ R $\mathrm{L}$ :

http://links.jstor.org/sici?sici=0002-9114\%28193410\%2F12\%2938\%3A4\%3C501\%3ATVOGFA\%3E2.0.CO\%3B2-0

NOTE: The reference numbering from the original has been maintained in this citation list. 